\title{
Analysis of Studies from 2000-2010 in Real Option Theory and Application to OM
}

\author{
Hui-Chuan Chen \\ University of Texas at Arlington, US \\ E-mail:hui-chuan.chen@mavs.uta.edu \\ Received February 20, 2011; revised March 21, 2011; accepted March 23, 2011
}

\begin{abstract}
Traditional project investment methods, such as the discounted cash flow (DCF) with a fixed static plan, are no longer sufficient to assist the corporate strategies of seizing opportunities and profitability. The option pricing formula includes a theoretical framework for pricing financial options, assuming that the risk in a financial hedged position is zero, if the option is adjusted continuously in a short position. Hence, the real options revolution arose in response to the dissatisfaction of corporation practitioners with traditional capital budgeting techniques, such as standard discount cash flow. This paper analyzes relevant articles from the "Journal of Operations Management" and "Management Sciences" as related to real options theory in the field of operations management. The goal of this study is to review and identify the gaps in application to real option theory in their studies. Finally, this paper provides suggestions for future researchers.
\end{abstract}

Keywords: Option Theory, Operations Management, Hedging, Flexibility

\section{Introduction}

In today's highly competitive business environment, corporate managers must constantly make decisions in response to the rapidly changing marketplaces, including new product introductions, information systems, research and development, as well as outsourcing of manufacturing. Company strategies must be flexible and agile in order to seize the opportunities and profitability. If managers can learn from their mistakes, and make adjustments to execute different options, companies can more quickly reach a higher profit than their competitors. Yeo and Qiu [1] mentioned that many of these managers now recognize that the traditional project investment methods, especially the discounted cash flow (DCF) based measures are no longer sufficient in the current rapidly changing environment. Traditionally, the DCF method provides a fixed static plan and expects that future plans will not be altered. However, this is no longer a suitable method. This study will provide an overview of real options theory and investigate the relevant literature to determine the gaps which occur when real options are implemented in the operations management field.Furthermore, this study will present some relevant propositions and pertinent questions for managers in decision making processes.

\section{Overview of Conventional Real Options Theory}

Black and Scholes [2] published the option pricing formula in 1973 with a theoretical framework for pricing financial options; specifically, they provide the basic assumption and equation that stock values follow a lognormal distribution progress,

$$
\frac{\mathrm{d} S}{S}=\mu \mathrm{d} t+\sigma \mathrm{d} z(1)
$$

where $S$ is the price of the stock, $\mu$ is the drift rate of $S, t$ is a time in years, $\sigma$ is the variation of the stock's returns, and $z$ is a Wiener process.Generally speaking, an option provides the holder the right to purchase or sell a share of stock at a specific price. The holders have the right to purchase a stock when it is a "call" option, and they also have the right to sell a stock when it is a "put" option. An organized traded call options started in April 1973, and in June 1977 the trading of put options followed [3]. An American option indicates that the option can be exercised at any time before maturity or the expiration date, whereas a European option can only be exercised on the expiration date. One early pricing theory proposed by Black and Scholes [2] states that at the maturity date and under risk neutral conditions, the price of a Euro- 
pean call option has a closed solution. They assume that the risk in the financial hedged position is zero if the option is adjusted continuously in a short position; however, if the position is not constantly modified, the risk is minimal, and is comprised entirely of risk that can be spread by shaping a portfolio of a great number of hedged positions [2]. The mathematical analysis for financial options through diversifying the risks has led to Cox and Ross' [4] risk neutral valuation model. They applied a series of binomial trees or the Monte Carlo method as option valuation techniques to represent future asset values. Cox and Ross further state that investors can expect returns and discount rates in a "realistic" risk free condition.They also pointed out that Black and Scholes' option pricing model relies only on observable variables under a static setting, as opposed to Cox and Ross' option valuation model which focuses on "the aggregate value of the claims against the returns of a firm" [4]. However, the risk neutral valuation may not be realistic for the business environment under many uncertainties and changes.

\section{New Directions for Real Options}

Trigeorgis [5] indicated that the real options revolution arose in response to the dissatisfaction of corporate practitioners using traditional capital budgeting techniques, such as standard discount cash flow. Yeo and Qiu [1] point out that the real options applications assist managers to gain a broader perspective and opportunities rather than a particular valuation. Thus, various investment scenarios can be seen as groups of options. Furthermore, the main difference between applying real option methods and financial options is that real options are relevant to real resources which are tangible, including machinery, factory, etc. Conversely, a financial asset normally includes stocks and bonds.

Some other distinctions between the financial options theory and the real options involve financial options having a shorter life-such as less than one year of expiration date, whereas real options can be long-lived. Additionally, financial options are fairly simple with a single exercise price, but the exercise price for real options differs from time to time. Yeo and Qiu [1] provide an example that investing in research and development (R\&D) produces an option to implement a technology with unknown benefits. If the investment is successful, there is a succeeding option to increase the product line. When the product is at the end of product stage, there is the option to abandon it. Moreover, the market position of the company may exercise the option to be influenced by a series of options and optimal timing.Amram and Kulatilaka [6] state that applying an options-based ap- proach is not merely the use of a new method of valuation equations and models. In fact, it involves a new approach of structuring strategic decisions. The managers must consider a sequence of strategies such as potential gains for the corporation by moving from position $\mathrm{A}$ to position B. It is similar to a decision tress with various options opening down to the decision paths.

Uncovering each step through the real options can be difficult. Real options are different from the financial options because real options are not specifically defined or clearly packaged. However, the options are actually present in many business decisions. Amram and Kulatilaka [6] and Yeo \& Qiu [1] indicate some of the hypothetical examples of the most general types of real options: "Timing options, Growth options, Staging options, Exit options, Flexibility options, Operating options, and Learning options."These common types of real options assist the companies to increase the scale by enhancing the upside potentials profits, without raising the downside of the risks. The next section will present some relevant articles which discuss the application of real options theory in the field of operations management.

\section{Literature Review of Real Options Applications in $\mathbf{O m}$}

Journal of Operations Management and Management Science are two well-established journals in the field of operations management research. The following literature review presented in this paper will focus on the relevance of real options applications within these two journals as related to practicing real options in $\mathrm{OM}$ and the application of simulation methods.

\subsection{Application of Real Options in the OM}

When corporations try to alleviate the risk, the real options can be demonstrated with financial and nonfinancial hedging for risk management strategies. Boyabatl and Toktay [7] indicate that real options are applied as operational hedging instruments. Much operational hedging has been demonstrated in a diversity of fields such as finance, strategy, operations management, and international business. Operational hedging comprises a major part of firm-level risk management decisions which show that firms actually exercise operational hedges in managing their risks. Specifically, Weiss and Maher [8] discuss how financial and operational hedging impacts the airline industry. After the events of September 11, 2001, airline industries realized the importance of managing financial distress under undesirable conditions and alleviating risk. Specifically, Weiss and Maher's research included nine U.S airlines with data 
covering 44 quarters from 1990 to 2000 examining the impact of the firms' performance under uncertainty on operational hedging to financial hedging. The attributes for operations hedging are represented by fleet diversification, load factor, lease, and domestic and the attributes for financial hedging are represented by fuel hedging, cash, financial leverage. The results show that the airlines involved in operational hedging can better respond to unfavorable events to reduce risks. Thus, in the case of the airline industry, financial hedging instruments (i.e., fuel price protection) are not as powerful as operations hedging.

Amram and Kulatilaka [6] address the flexibility options when demand is uncertain for new products; however, forecasts imply that sales targets would be reached across two continents. Thus, the managers should decide whether to build a single plant in one continent or two plants on two continents. The flexibility option will be taken into account when the value of the option outweighs the costs saved by only building one plant. In another study, Jack and Raturi [9] infer that volume flexibility assists the handling of the aggregate demand uncertainty. Volume flexibility allows the company to change production upwards and downwards within broad limits. However, the implementation of flexibility in capabilities may not be easily exercised or accurately measured. Therefore, modular product design permits firms to buffer processes with a list of "modules" in which the span of processes can be buffered resulted in increasing demand uncertainties. Additionally, modular product design and a list of "modules" improve the volume flexibility by generating options for the firm which did not exist before. Their research applied the findings into a survey of 140 valid business respondents to see how each firm employs its resources to accomplish volume flexibility. The results indicated that both small and large firms depend on overtime source as a key shortterm option of volume flexibility; however, small firms are more efficient at using inventory and capacity buffers (short-term sources) of volume flexibility to react to variations in demand while large firms are better stand on taking competitive advantage through the long-term sources (such as supply chain networks and outsourcing arrangements) of volume flexibility. The findings further suggest that volume flexibility for short and long-term sources has a positive impact on both delivery and financial performance.

da Silveria [10] describes the challenge for many operations seeking flexibility without any negative effect on expenditures, quality, delivery, or performance. The flexibility model which included 285 manufacturers of fabricated metal products, machinery, and equipment from 14 countries revealed that flexibility competence could be built by structuring simplicity and discipline in manufacturing. da Silveria further stated that simplicity without lowering the number of options offered to the firm should deliver a rationalized process that is easier to adapt and reconfigure to altering requirements; likewise, discipline, as opposed to "stiffening procedures and skills," will enable a firm to response to changes in the marketplace, while promoting improved practices and work processes. The results provided the flexibility improvements have a positive relationship between simplicity and discipline in manufacturing. Especially, the relationships were stronger in high volume processes than in low volume processes.

Sawhney [11] applied flexibility simultaneously between the reactive and proactive approach to assist managers with their daily operational decision making among the supply chain systems. The reactive approach is addressed when organizations deal with different types of uncertainty which extend from the up and down to the basic task within the firm. As for proactive approaches, it has been argued that flexibility can be used proactively to generate competitive advantages for a firm. Thus, the area of flexibility is hierarchical, and it bi-directs from up to downstream or vice-versa within a single firm. Moreover, the flexibility under application of reactive and proactive is in a sequential approach which provides additional options for managers planning strategies across the supply chain to create value for the customers and the firm.

Furthermore, Pagell and Krause [12] have considered the relationship between uncertainty and flexibility, and between flexibility and performance. However, their study presented doubts regarding the earlier results. Pagell and Krause replicated the model of Swamidass and Newell [13] and focused on surveys but found no relationship between increased uncertainty and increased flexibility under cross-industry sample of manufacturing firms. Additionally, there is little supporting evidence when higher levels of flexibility in uncertain environments were associated with higher levels of performance. Thus, it was suggested that a more thorough research study should involve industry and business strategy.

Under mass customization, customers are highly involved in specifying the product, whereas manufacturers can produce high volumes of products. In other words, customers can purchase a customized product without sacrificing economies of scale from the cost of a mass production item. Additionally, during mass customization, the manufacturers must attend to each customer's specifications in product design. Duray et al. [14] recommended that the manufacturers employ a modular design to achieve manufacturing efficiencies to approximate the standardization of mass production. Their 
study found that utilizing the modularity in the later phases of production may improve performance for mass customizers. Moreover, the results showed that when mass customizers approach mass production, profitable scales of economy and better financial performance can be achieved.

Dilts and Pence [15] studied whether the role of decision maker-project manager or executive sponsorwould impact the termination a public sector project. Different functional managers have different project perceptions while an individual manager interprets the projects differently; therefore, this will affect how the managers' decisions whether to continue or terminate the projects. Moreover, other reasons to terminate the projects include how much effort and money the managers have devoted, how rapid and uncertainty the external environment changes, or how big or small the scale of the projects are. Also, there are tendencies for individual decision makers to add more resources (sunk costs) already consumed in a failed project. The final finding from Dilts and Pence's study indicated that two key factors have statistically significant difference between executive and project managers. Executives think that variance in overall project complexity and in time to completion are less significant than the project managers. In other words, project managers (when compared to executives) have a higher tendency to terminate a project which is running overtime.

Folta, Delmar, and Wennberg [16] applied the hybrid entrepreneurship to study how individual's decision to opt for self-employment. They defined hybrid entrepreneurs as individuals who take on self-employment while holding a primary job in some other organization. The authors described that the hybrid entrepreneurship is most likely to experience the entrepreneurial waters before becoming fully immersed into self-employment. Through this experience, individuals can learn the venture's potential advantages whether they can adapt to the self-employment surroundings. When individuals are less confident, this mode of entry might assist them to limit their sunk costs while they collect evidence to better understand the unknown capabilities. Furthermore, a real option may be characterized under small-scale entry with hybrid entrepreneurship to invest heavily when early returns are showing and to retire if they are not. This situation can also be explained by determining when the switching or opportunity costs are high; the individual might delay being fully self-employed. Research has shown that the hybrids often leave wage work and join self-employment when there is a positive signal about performance prospects; however, the hybrids may leave their self-employment while there is a negative signal. Otherwise, individuals might stay in hybrid status until there is a clear signal. This leads to the conclusion drawn that hybrid entrepreneurship is attractive due to its avoidance ofswitching costs such as losing retirement benefits, healthcare, or seniority status to maintain the flexibility and option value related to delay entrepreneurial access. The next section will provide some simulation designs that may occur under real options applications.

\subsection{Simulation Method Applications in OM}

Managers are often concerned about making tough decisions that require choosing among various competing designs within the firms' manufacturing, supply chain, or service delivery system. Simulations can be a part of methods to assist the managers for determining alternative designs. However, the time needed to do the simulation or which given simulation results to implement is another important decision for the managers. Thus, if the goal is to choose the high-level system design with maximize expected net present value (NPV), the manager may encounter more simulations to decrease the uncertainty or delay in project implementation by applying more simulations. Ranking and selection procedures which provide a preferred level of statistical evidence in best performance are one of the frequent approaches for selecting a finite set of simulated systems. Additionally, Chick and Gans [17] stated that the ranking and selection methods attempt to minimize the mean number of simulations necessary to achieve a preferred level of statistical evidence for appropriate selection. However, it was emphasized that the statistical significance might not be the same as financial significance; therefore, when simulation results and system performance are used as financial measures, the maximization of expected NPV can be a more appropriate objective. The simulations are based on managers having prior confidence regarding the distribution of the NPV of these. Eventually, the authors designed their study to respond to the issue under simulation with financial measures such as marginal cost under optimization controlto apply operational decisions.

Gamba and Fusair [18] stated that real options theory presents an ordinary framework to achieve value creation from modular design. Furthermore, they explain that the modularization process is a detailed description which can be defined by a number of parameters and their associations. Additionally, they point out that a module is determined by a group of strongly interconnected factors that are typically independent from the factors of other modules. Similarly, Baldwin and Clark [19] indicated that module design is to exhibit modularity in design under a complex system. If the modularitysegments can be constructed independently, the design 
Table 1. Literature review summary

\begin{tabular}{|c|c|c|c|c|}
\hline Journal & Author(s) & Valid Data & Topic & Results \\
\hline JOM & $\begin{array}{l}\text { Weiss \& Maher } \\
\text { (2009) }\end{array}$ & 11 US Airlines & $\begin{array}{l}\text { Operational vs. financial } \\
\text { hedging }\end{array}$ & $\begin{array}{l}\text { Operational hedging vehicles are more powerful in } \\
\text { protecting firms than using financial instruments. }\end{array}$ \\
\hline $\mathrm{JOM}$ & Sawhney (2006) & $\begin{array}{l}64 \text { Printed Circuit } \\
\text { board plants }\end{array}$ & $\begin{array}{l}\text { Flexibility vs. reactive and } \\
\text { proactive }\end{array}$ & $\begin{array}{l}\text { Flexibility under application of reactive and proac- } \\
\text { tive is in a sequential approach which provides } \\
\text { additional options across the supply chain. }\end{array}$ \\
\hline JOM & $\begin{array}{l}\text { de Silveira } \\
\text { (2006) }\end{array}$ & $\begin{array}{l}285 \text { manufacturers } \\
\text { from } 14 \text { countries }\end{array}$ & $\begin{array}{l}\text { Flexibility vs. simplicity \& } \\
\text { discipline }\end{array}$ & $\begin{array}{l}\text { Flexibility improvements have a positive relation- } \\
\text { ship between simplicity and discipline in manufac- } \\
\text { turing. }\end{array}$ \\
\hline JOM & $\begin{array}{l}\text { Dilts \&Pence } \\
\quad \text { (2006) }\end{array}$ & $\begin{array}{l}55 \text { worked for Na- } \\
\text { tional Institute of } \\
\text { Justice public projects }\end{array}$ & $\begin{array}{l}\text { Executives \& Project man- } \\
\text { agers' role in termination } \\
\text { projects }\end{array}$ & $\begin{array}{l}\text { Project managers are more likely to terminate a } \\
\text { project that is running overtime than are executives. }\end{array}$ \\
\hline JOM & $\begin{array}{l}\text { Pagell \& Krause } \\
\qquad(2004)\end{array}$ & $\begin{array}{l}252 \text { members of the } \\
\text { Institute of Supply } \\
\text { Management (ISM) }\end{array}$ & $\begin{array}{l}\text { Flexibility vs. uncertain \& } \\
\text { performance }\end{array}$ & $\begin{array}{l}\text { The results show that there is no evidence to sup- } \\
\text { port higher levels of flexibility in uncertain envi- } \\
\text { ronments when associated with higher levels of } \\
\text { performance. }\end{array}$ \\
\hline JOM & $\begin{array}{l}\text { Jack\& Raturi } \\
\quad(2002)\end{array}$ & $\begin{array}{l}\text { Three case studies \& } \\
\quad 140 \text { survey }\end{array}$ & $\begin{array}{l}\text { Volume Flexibility \& Per- } \\
\text { formance }\end{array}$ & $\begin{array}{c}\text { Volume flexibility for short and long-term options } \\
\text { has a positive impact on both delivery and financial } \\
\text { performance. }\end{array}$ \\
\hline JOM & $\begin{array}{l}\text { Duray et al. } \\
\quad(2000)\end{array}$ & 194 manuf. Plants & $\begin{array}{l}\text { Mass Customization \& } \\
\text { Modular Design }\end{array}$ & $\begin{array}{l}\text { When mass customizers approach mass production, } \\
\text { they can reach economies of scale and better finan- } \\
\text { cial performance items. }\end{array}$ \\
\hline MS & $\begin{array}{l}\text { Folta, Delmar \& } \\
\text { Wennberg (2010) }\end{array}$ & 45,000 Swedish men & $\begin{array}{l}\text { Hybrid entrepreneurship vs. } \\
\text { complete immersion in self- } \\
\text { employment }\end{array}$ & $\begin{array}{l}\text { Hybrid entry is preferred to self-employment entry } \\
\text { with more capable, lower switching costs, and less } \\
\text { self-employment experience. }\end{array}$ \\
\hline MS & $\begin{array}{l}\text { Chick and Gans } \\
\text { (2009) }\end{array}$ & Simulation & $\begin{array}{l}\text { Max. NPV vs. Min. replica- } \\
\text { tions }\end{array}$ & $\begin{array}{c}\text { It links financial measure to optimal control of } \\
\text { simulation experiments that are designed to inform } \\
\text { operational decisions. }\end{array}$ \\
\hline MS & $\begin{array}{l}\text { Gamba \& Fusari } \\
\text { (2009) }\end{array}$ & Simulation & $\begin{array}{l}\text { Valuing Modularity vs. real } \\
\text { option }\end{array}$ & $\begin{array}{l}\text { Based on modularization in the design of a system } \\
\text { for capital budgeting decisions. }\end{array}$ \\
\hline MS & $\begin{array}{c}\text { Kumar \& } \\
\text { Turnbull (2008) }\end{array}$ & None & $\begin{array}{l}\text { Optimal patenting \& licens- } \\
\text { ing of financial innovations }\end{array}$ & $\begin{array}{l}\text { A parsimonious framework is developed to assist } \\
\text { the managers whether to patent under consideration } \\
\text { for a financial institution. }\end{array}$ \\
\hline
\end{tabular}

will interconnect to support the whole. Furthermore, Gamba and Fusair considered six operators (splitting, substitution, augmenting, excluding, inversion, and porting) which can be defined as options were chosen to describe the evolution from a nonmodular design to a modular design. Thus, there is a need to link modularity and real option theory to practice. In addition, Gamba and Fusair combined Baldwin and Clark's six modular operators to implement the simulations with each operator. Thus, the purpose for these operators is intended to create value, while the natural valuation application depends on claim analysis employed to optional investment decisionswhich comprisereal options theory.

Financial institutions, which are also applicable for real options, often develop different types of innovations in financial services and products. In order to protect these innovations, financial managers have the option to decide whether to obtain patents, patents and licensing, or none at all. Kumar and Turnbull [20] mentioned that without such measures, the innovating institution has no legal right to seek a judgment if there is imitation. Therefore, while larger financial firms generally patent, nonfinancial institutions file for more patents compared to financial firms. Please see Table 1.Literature Review Summary.

\section{Identifying the Gaps in the Literature \& Propositions}

Based on the literature review above, this section identi- 
fies the lack of real world applications for option theory. Weiss and Maher [8] clearly applied real options (hedging) to understand how airlines manage to alleviate the risk.However, while many firms incorporate flexibility into their strategic planning, the studies do not specifically apply real options theory into the research. For example, both Jack and Raturi [9] and da Silveria [10] used flexibility for their research on volume productions. However, they did not consider whether building flexibility increases the overall corporation value. Thus, these studies could have included Mello, Parsons, and Triantis [21]'s flexibility study in sourcing its production to hedge exchange rate risk in financial markets. The degree of flexibility for production is directly link with the firm's financial policy. Therefore, the following propositions are established:

- Proposition 1. Higher degree of production flexibility is positively related to a firm's willingness to hedge its financial assets.

For example, Sawhney [11] studied options for both suppliers and customers' flexibility to reduce the manufacturing uncertainty. He provided a transformation framework of flexibility for his model. Also, he discusses how flexibility assists the companies to reduce costs. Nevertheless, the manner in which these different flexibilities affect the financial impact of the firms is not addressed. Pagell and Krause [12] studied the flexibility and firms' performance, and they tried to evaluate the flexibility with some financial impact such as growth in sales and returns for the firms. However, they did not find a significant relationship between the flexibility and performance. Duray et al. [14] utilized mass customization with modular design to achieve high performance. Since a positive relationship between mass customization and financial performance was observed, I contend that:

- Proposition 2. The higher the mass customization utilized in the firm, the more likely it is to build stronger flexibility in the firm and its financial performance.

Many research studies have presented different options and provide simulations to investigate which option can offer the highest value for the corporations. These options and simulations are usually predetermined by the managers who make the final decision, resulting in the highest value of simulation. Thus, these options are quite difficult to utilize in real world examples. For example, Boyabatl and Toktay [7] provided some real options among operational flexibility. The firms have options whether or not to engage in a multinational investment by obtaining a level of profits. As real options apply to manage the risk of inventories related to uncertain demand, retailers and manufacturers often arrange reorder- ing contracts, or call options which permit the retailer to purchase additional merchandise at a pre-decided time for a fixed price and return contracts, or put options which let the retailer to return unsold products at a predetermined salvage value [22]. According to Pandza et al. [23], by delaying investments through waiting for market and technology uncertainty to diminish, the real options logic can identify the value available to firms by waiting before proceeding into a larger commitment.

- Proposition 3. Higher uncertainty in market and technology will delay firms' decisions to proceed with additional investment.

Overall, the above analysis reveals that the gaps between real world applications and utilizes real options practices to assist managers in deciding the companies' future strategic planning. The propositions facilitate some direction for managers when utilizing option theory.

\section{Implications and Future Research Directions}

From the above discussion, it is evident that a fundamental gap exists between utilizing real option and simulation in real world scenarios. Since it is important for managers to simulate some options before applying the flexibility model, the risk of the uncertainty when the firms invest in any future projects can be alleviated. Several of the articles cited above for flexibility applications such as da Silveria [10], Sawhney [11], Jack and Raturi [9], Pagell and Krause [12], and Duray et al. [14], and with Gamba and Fusari's [18] for simulation under modularity valuing can be expanded to establish some research questions and models. Due to the above research implementation of slightly different flexibility approaches, this section of the present study focuses on Sawhney's [11] article regarding some questions that could be extended when applying real options under certain simulations.

In Table 2, the author studied the upstream (supplier flexibility) and downstream (customer flexibility) and the relationship between input, process, and output flexibility. While not addressing any values to help the firms' generate higher revenue, Sawhney indicates that flexibility will impact the suppliers and customers' flexibility. Therefore, the managers can ask: Which flexibility option can assist the firm to generate the most value through implementation of those decisions? By implementing the flexibility option in each stage, does the firm create incremental value by taking advantage of theupside potential profits? Sawhney specified sixteen propositions for his research; in this study, it is proposed 


\section{H. CHEN}

Table 2. Sawhney (2006) transformation framework of flexibility.

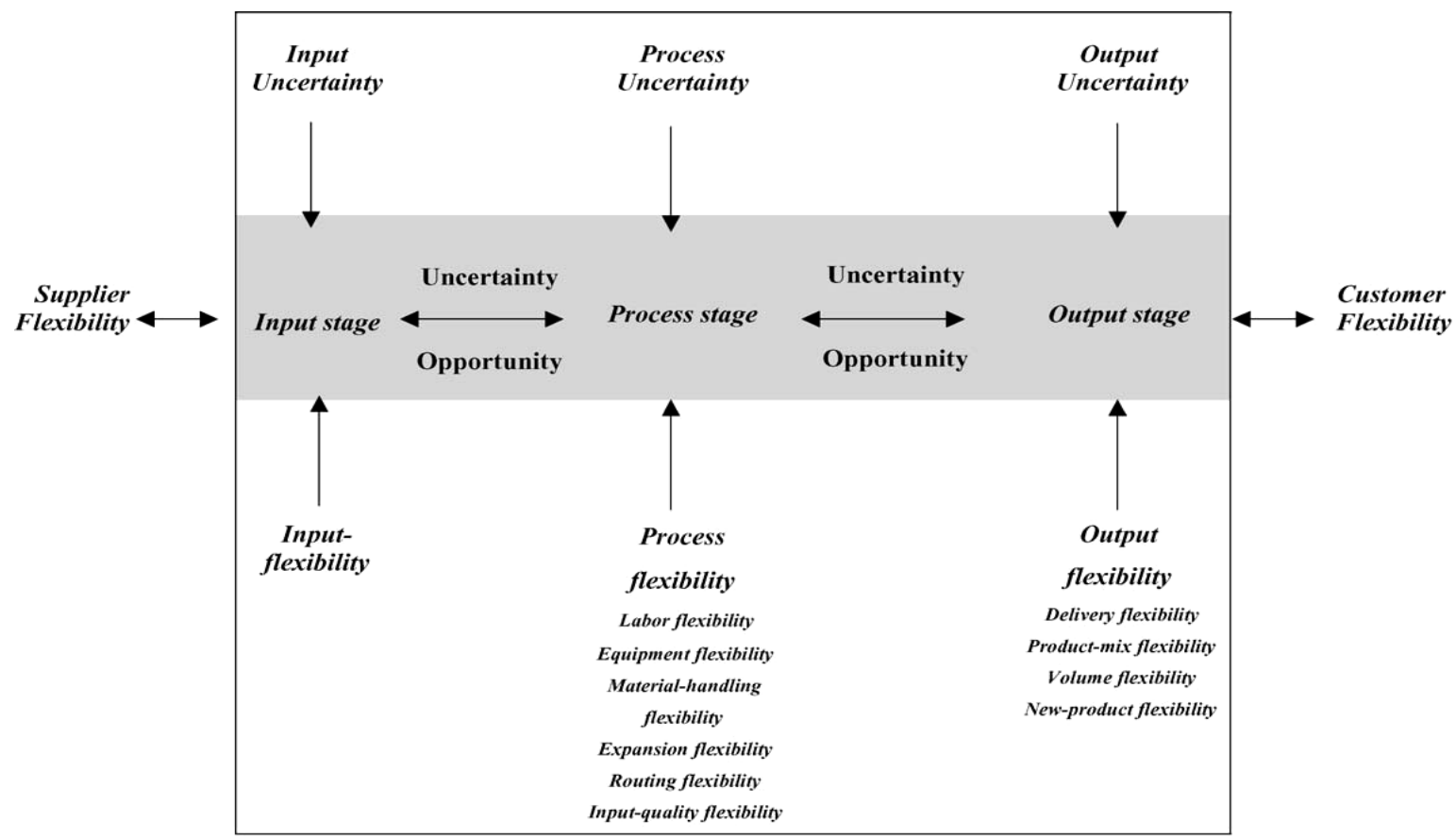

Manufacturing firm

that this research could be modified by using each of his propositions as an option to determine whether to implement or delay the actions under consideration.

Since Black and Scholes' [2] original option pricing formula was proposed in 1973 to Cox and Ross' [4] risk neutral valuation model, options have been applied from the financial field to various business areas. Corporations have utilized options to help firms alleviate the uncertainty and risk, thereby allowing them to increase value and profits. Many researchers have published related topics in applying flexibility and real options in some of the research. Specifically, JOM includes several articles related to flexibility for their studies and MS focuses on how to implement real options in simulation form. Due to the challenges of institutionalizing the process to connect the real option theory in actual scenarios, few articles have been published on the application side. This review defines the gaps, proposes propositions, and builds on Sawhney's study to arrive at some research questions for the real option decision within a flexibility approach. It is hoped that this proposal can assist managers to make better decisions in generating corporate profits while dealing with the uncertainty and avoiding risk.

\section{References}

[1] Yeo, K.T. \& Qiu, F. (2003). The value of management flexibility - a real option approach to investment evalua- tion. International Journal of Project Management, 21, 243-250.doi:10.1016/S0263-7863(02)00025-X

[2] Black, F. \& Scholes, M. (1973). The Pricing of Options and Corporate Liabilities. The Journal of Political Economy, 81(3), 637-654.doi:10.1086/260062

[3] Merton, R.C., Scholes, M.S., \& Gladstein, M.L. (1982). The Returns and Risks of Alternative Put-Option Portfolio Investment Strategies. Journal of Business,55(1), 1-55. doi:10.1086/296153

[4] Cox, J.C. \& Ross, S.A. (1976). The Valuation of Options for Alternative Stochastic Processes. Journal of Financial Economics, 3, 145-166. doi:10.1016/0304-405X(76)90023-4

[5] Trigeorgis, L. (1993). Real Options and Interactions with Financial Flexibility. Financial Management, 22(3), 202224.

[6] Amram, M. \& Kulatilaka, N. (1999). Disciplined decisions: aligning strategy with the financial markets. Harvard Business Review, 77(1), 95-104.

[7] Boyabatl1, O. and L. B. Toktay. (2004). Operational hedging: a review with discussion. Working Paper. INSEAD.

[8] Weiss, D. \& Maher, M.W. (2009). Operational hedging against adverse circumstances.Journal of Operations Management, 27, 362-373. doi:10.1016/j.jom.2008.10.003

[9] Jack, E. P. andRaturi, A. (2002).Sources of volume flexibility and their impact on performance.Journal of Operations Management, 20, 519-548. doi:10.1016/S0272-6963(01)00079-1 
[10] da Silveira, G. (2006). Effects of simplicity and discipline on operational flexibility: An empirical reexamination of the rigid flexibility model. Journal of Operations Management, 24, 932-947. doi:10.1016/j.jom.2005.11.004

[11] Sawhney, R. (2006). Interplay between uncertainty and flexibility across the value-chain: Towards a transformation model of manufacturing flexibility. Journal of Operations Management, 24, 476-493. doi:10.1016/j.jom.2005.11.008

[12] Pagell, M. and Krause, D.R. (2004). Re-exploring the relationship between flexibility and the external environment. Journal of Operations Management, 21, 629649.doi:10.1016/j.jom.2003.11.002

[13] Swamidass, P.M., and Newell, W.T. (1987). Manufacturing strategy, environmental uncertainty and performance: a path analytic model. Management Science, 33, 509-524. doi:10.1287/mnsc.33.4.509

[14] Duray, R., Ward, P., Milligan, G., \& Berry, W. (2000). Approaches to mass customization: configurations and empirical validation. Journal of Operations Management, 18, 605-625.doi:10.1016/S0272-6963(00)00043-7

[15] Dilts, D.M. and Pence, K.R. (2006). Impact of role in the decision to fail: An exploratory study of terminated projects. Journal of Operations Management, 24, 378-396. doi:10.1016/j.jom.2004.12.001

[16] Folta, T., Delmar, F., \& Wennbery, K. (2010). Hybrid Entrepreneurship. Management Science, 56(2), 253-269. doi:10.1287/mnsc.1090.1094
[17] Chick, S. \& Gans, N. (2009). Economic Analysis of Simulation Selection Problems. Management Science, 55(3), 421-437.doi:10.1287/mnsc.1080.0949

[18] Gamba, A. \& Fusari, N. (2009). Valuing Modularity as a Real Option. Management Science, 55(11), 1877-1896. doi:10.1287/mnsc.1090.1070

[19] Baldwin, C.Y. and Clark, K.B. (2006). The Architecture of Participation: Does Code Architecture Mitigate Free Riding in the Open Source Development Model? Manag-ement Science, 52(7), 1116-1127. doi:10.1287/mnsc.1060.0546

[20] Kumar, P. and Turnbull, S.M. (2008). Optimal Patentingand Licensing of Financial Innovations. Management Science, 54(12), 2012-2023. doi: $10.1287 / \mathrm{mnsc} .1080 .0898$

[21] Mello, A.S., Parsons, J.E., and Triantis, A. (1995). An Integrated Model of Multinational Flexibility and Financial Hedging. Journal of International Economics, 39(12), 27-51.doi:10.1016/0022-1996(94)01362-V

[22] Burnetas, A. and Ritchken, P. (2005). Option Pricing with Downward-Sloping Demand Curves: The Case of Supply Chain Options. Management Science, 51(4), 566580.doi:10.1287/mnsc.1040.0342

[23] Pandza, K., Horsburgh, S., Gorton, K., and Polajnar, A. (2003). A real options approach to managing resources-and capabilities. International Journal of Operations \& Production Management, 23(9), 1010-1032. doi:10.1108/01443570310491756 